\title{
Microbiological Quality of Catfish (Clarias Gariepinus) and Tilapia (Tilapia Mossambica) Obtained from Wet Markets and Ponds in Malaysia
}

Titik Budiati ${ }^{1 *}$, Gulam Rusul' ${ }^{2}$, Wan Nadiah Wan-Abdullah ${ }^{3}$, Rosma Ahmad ${ }^{3}$ and Yahya Mat Arip ${ }^{4}$

${ }^{1}$ Food Technology Department, State Polytechnic of Jember, 68121, Jember, Indonesia

${ }^{2}$ Food Technology Division, School of Industrial Technology, University of Science, Malaysia, 11800, Penang, Malaysia

${ }^{3}$ Bioprocess Technology, School of Industrial Technology, University of Science, 11800, Penang, Malaysia

${ }^{4}$ School of Biological Science, University of Science, Malaysia, 11800, Penang Malaysia

\begin{abstract}
The aim of this study was to determine the microbiological quality in catfish (Clarias gariepinus) and tilapia (Tilapia mossambica) obtained from wet markets and ponds in Malaysia. A total of 108 samples (32 catfish, 32 tilapia, and 44 water samples) were obtained from nine wet markets and eight ponds in Penang, Malaysia. The feed in fish ponds were chicken offal, spoiled eggs and commercial fish feed. Using standard procedures, aerobic plate counts (APC), coliform, fecal coliform including E. coli were performed. A total 31/32 of catfish and 31/32 of tilapia exceeded the recommended microbiological standard for the APC. E. coli was less than $3 \mathrm{MPN} / \mathrm{g}$ for all catfish and tilapia samples. Temperature and $\mathrm{pH}$ of water ponds ranged from 26 to $27.5^{\circ} \mathrm{C}$ and 6 to 6.8 , respectively. Homemade feed using chicken offal and spoiled egg may contribute to the microbiological quality in fish. This highlights the importance of feed in aquaculture system.
\end{abstract}

Keywords: Catfish; Microbiological quality; Pond; Tilapia; Wet market

\section{Introduction}

Aquaculture, an important sector, has significant economic impact in many countries including Malaysia. Based on the recent data, freshwater fish is cultured using pond culture, ex-mining pool, freshwater cage, cement tank, canvas tank, and freshwater pen culture systems [1]. The highest freshwater fish production in Malaysia was catfish reared in pond culture $(64.9 \%)$ followed by tilapia reared in ex-mining pools (18.2\%) [1]. FAO [2] reported that aquaculture production in Malaysia is marketed locally for domestic consumption. Besides quantity of aquaculture production, the application of hygiene and food safety procedures in fish production should be taken into account [3]. The inappropriate aquaculture practice may become a concern for food safety issue [4]. Yet, intensification of fish production is still raising the risk of disease due to high density stocking of fish, antibiotics, poor water control and other factors [3]. Feed, an important diet for the growth of fish $[5,6]$, may promoted the risk of disease for fish and ultimately for human [7]. In Asia-Pacific region, commercial feed and home-made feed have been used to feed the fish in freshwater aquaculture production. The home-made feed was chicken offals, spoiled eggs or waste food [8] which may affect to the quality of fish.

However, there is still limited data regarding the microbiological quality of fish distributed in Malaysia which were fed using homemade feed (chicken offal or spoiled eggs) and commercial feed. The microbiological quality of fish can be measured by using aerobic plate counts, coliform counts, fecal coliform counts and E. coli counts. Thus, this study was carried out to fill in this gap. The aim of this study was to determine the microbiological quality of catfish (Clarias gariepinus) and tilapia (Tilapia mossambica) obtained from wet markets and ponds (fed with chicken offals, spoiled eggs or commercial fish feed) in Malaysia.

\section{Materials and Methods}

\section{Samples}

Catfish and water samples were collected from local wet markets
(A,B,C,D, and E), pond A1, Pond A2, Pond B1 and Pond B2. Tilapia and water samples were collected from local wet markets (E,F,G, and $\mathrm{H}$ ), pond C1, Pond C2, Pond D1 and Pond D2. Alive catfish and tilapia was placed in sterile plastic bag that was filled with water. Further, the plastic bag was filled with oxygen and banned with rubber. Dead tilapia obtained from wet market was placed in sterile plastic bag and kept in the box with temperature approximately $4^{\circ} \mathrm{C}$ during transportation to the laboratory. Water samples were collected using sterile test tubes, and then transferred to the laboratory in ice box with temperature approximately $4^{\circ} \mathrm{C}$. The samples were proceeded in the laboratory within 6 hours. Ponds A1 and Pond A2 used chicken offal to fed catfish. Pond C1 and C2 used spoiled egg to fed tilapia. Pond B1, B2, C1 and C2 used commercial fish feed.

\section{Determination of aerobic plate count (APC)}

Twenty five grams of catfish or tilapia was mixed with $225 \mathrm{~mL}$ of $0.1 \%$ Pepton Water (PW, Oxoid, Baringstoke, Hampshire, United Kingdom) and homogenized by using stomacher (Interscience, France) for $120 \mathrm{sec}$. The dilution was prepared by pipeting $1 \mathrm{~mL}$ of aliquot and mixed with $9 \mathrm{~mL}$ of $0.1 \% \mathrm{PW}$. The dilution was made from $10^{-1}$ to $10^{-6}$. About $100 \mathrm{~mL}$ of aliquot was spread on Plate Count Agar (PCA, Merck KGaA, Darmstadt, Germany) and incubated at $37^{\circ} \mathrm{C}$ for 24-48 h. Total number of colonies were counted and calculated as BAM Manual Protocol [9]. Total aerobic count was expressed as $\log \mathrm{cfu} \mathrm{g}^{-1}$. Twenty five millilitres of water sample was mixed with $225 \mathrm{~mL}$ of $0.1 \%$

*Corresponding author: Titik Budiati, Food Technology Department, State Polytechnic of Jember, 68121, Jember, Indonesia, Tel: 62-331-333532; E-mail: titik.budiati@gmail.com

Received October 20, 2014; Accepted November 07, 2014; Published January 10,2015

Citation: Budiati T, Rusul G, Wan-Abdullah WN, Ahmad R, Arip YM (2015) Microbiological Quality of Catfish (Clarias Gariepinus) and Tilapia (Tilapia Mossambica) Obtained from Wet Markets and Ponds in Malaysia. J Aquac Res Development 6: 291. doi:10.4172/2155-9546.1000291

Copyright: (C) 2015 Budiati T, et al. This is an open-access article distributed under the terms of the Creative Commons Attribution License, which permits unrestricted use, distribution, and reproduction in any medium, provided the original author and source are credited. 
PW and homogenized by using stomacher for $120 \mathrm{sec}$. The dilution was prepared from $10^{-1}$ until $10^{-6}$ and plated on PCA as BAM Manual Protocol. Aerobic Plate Count (APC) was determined by using spread method and incubated at $37^{\circ} \mathrm{C}$ for $24-48 \mathrm{~h}$ [9]. This was expressed as $\log \mathrm{cfu} \mathrm{mL}^{-1}$

\section{Determination fecal coliform count}

Fecal coliform counts were determined using MPN method [10]. The equipment and solutions were sterilized in an autoclave before each use. The microbial quality of the catfish and tilapia were assessed by sampling $25 \mathrm{~g}$ of catfish and tilapia. One $\mathrm{mL}$ of each dilution $\left(10^{-1}\right.$ until $10^{-5}$ ) was transferred into three tubes of Lauryl Sulfate Tryptose Broth (LST, Oxoid, Baringstoke, Hampshire, United Kingdom) and incubated at $37^{\circ} \mathrm{C}$ for 24 hours. Approximately, $10 \mu \mathrm{L}$ of LST broth from positive tubes were transferred into $10 \mathrm{~mL}$ of Brilliant Green Lactose Bile Broth (BGLB, Merck KGaA, Darmstadt, Germany) and incubated at $37^{\circ} \mathrm{C}$ for $24 \mathrm{~h}$. Turbid tubes with gas were considered as positive and coliform counts were expressed as MPN g-1 or MPN mL $\mathrm{mL}^{-1}$.

Fecal coliform bacteria are used as the fecal indicator in guidelines for wastewater reuse in irrigation and aquaculture [11]. Therefore, the water in the fish ponds was subjected to microbiological investigation using fecal coliforms as indicators of fecal pollution. Fecal coliform count was determined by transferring $10 \mu \mathrm{L}$ of LST broth from positive tubes into three tube of Escherichia coli Broth (EC, Merck KGaA, Darmstadt, Germany) and was incubated at $44-45^{\circ} \mathrm{C}$ for $24 \mathrm{~h}$. Tubes showing gas and turbidity were considered positive for the presence of fecal coliform and these were expressed as MPN g ${ }^{-1}$ or MPN mL ${ }^{-1}$. A loopful of broth in gasing tube was streaked on L-EMB agar (Merck, Germany) and incubated at $35^{\circ} \mathrm{C}$ for $18-24 \mathrm{~h}$. Presumptive E. coli grew as distinctive metallic green sheen colony on L-EMB Agar. Biochemical tests such as gram staining, catalase, cytochrome oxidase, microscopic observation, indole production, Voges-Proskauer reaction, methyl read reaction, citrate production and re-inoculated back into LST to confirm gas production were carried out as the Bacteriological
Analytical manual [10]. E. coli culture (Food Microbiology Laboratory, School of Industrial Technology, USM) was used as control.

\section{Temperature and $\mathrm{pH}$ of water analyses}

Temperature and $\mathrm{pH}$ of water ponds were measured using Portable Digital pH Meter (Hanna, Model HI 8424, Romania). The sampling was measured every sampling day between 09.00 and 10.00 a.m.

\section{Statistical Analysis}

The statistical analysis of APC, coliform, faecal coliform and E. Coli in catfish obtained from different wet market and ponds were determined by using one-way ANOVA (SPSS software for Windows Version 13) at the significance level $(\mathrm{P}<0.05)$. The same statistical analysis was also applied for APC, coliform, faecal coliform and E. coli in tilapia obtained from different wet market and ponds. In similar, one way ANOVA was applied to determine APC, coliform, faecal coliform, E. coli, temperature and $\mathrm{pH}$ of water obtained from different wet market and ponds.

\section{Results}

\section{Aerobic plate counts}

Aerobic plate counts (APC) are a widely accepted measure of the general degree of microbial contamination [12]. In this study, the mean APC values were ranged from 5.30 to $6.84 \log 10 \mathrm{cfu} \mathrm{g}^{-1}$ for catfish and 5.77 to $9.12 \log 10 \mathrm{cfu} \mathrm{g}^{-1}$ for tilapia (Table 1). There was no significant different $(\mathrm{P}>0.05)$ among total aerobic bacteria in the catfish obtained from the ponds. Similarly, there was also found in tilapia obtained from all of the ponds (Table 1). However, there was significant different $(\mathrm{P}<0.05)$ between total bacteria in catfish obtained from wet market $\mathrm{D}$ (Gelugor wet market) and other markets. The significant different $(\mathrm{P}<0.05)$ was also observed between total bacteria in tilapia obtained from two markets $(\mathrm{F}, \mathrm{G})$ and other markets $(\mathrm{E}, \mathrm{H})$.

This present study found that $31 / 32$ of catfish and $31 / 32$ of tilapia

\begin{tabular}{|c|c|c|c|c|c|c|c|c|c|}
\hline \multirow[t]{2}{*}{ Location } & \multicolumn{3}{|c|}{$\begin{array}{c}\text { Total aerobic counts } \\
\left(\log \text { CFU g } \text { g }^{-1} \text { or log CFU } \mathrm{mL}^{-1}\right)\end{array}$} & \multicolumn{3}{|c|}{$\begin{array}{c}\text { Coliform counts } \\
\text { ( Log MPN g-1 or Log MPN mL-1) }\end{array}$} & \multicolumn{3}{|c|}{$\begin{array}{c}\text { Fecal coliform counts } \\
\text { ( Log MPN g-1 or Log MPN mL-1) }\end{array}$} \\
\hline & Catfish & Tilapia & Water & Catfish & Tilapia & Water & Catfish & Tilapia & Water \\
\hline \multicolumn{10}{|l|}{ Wet market } \\
\hline A (Bukit Mertajam) & $6.84 \pm 0.04^{e}$ & NA & $7.12 \pm 0.82$ & $2.81 \pm 1.09^{c d}$ & NA & $3.7 \pm 0.43^{\mathrm{de}}$ & $1.11 \pm 0.44^{c}$ & NA & $1.12 \pm 0.48$ \\
\hline B (Bagan Ajam) & $6.76 \pm 0.02^{\mathrm{de}}$ & NA & $7.07 \pm 0.41$ & $3.56 \pm 0.34^{\mathrm{cd}}$ & NA & $3.96 \pm 0.07^{\mathrm{de}}$ & $1.04 \pm 0.49^{c}$ & NA & $1.01 \pm 0.37$ \\
\hline C (Nibong Tebal) & $5.86 \pm 0.04^{\mathrm{cd}}$ & NA & $7.25 \pm 0.39$ & $3.75 \pm 0.26^{\mathrm{cd}}$ & NA & $3.77 \pm 0.23^{\text {cde }}$ & $0.97 \pm 0.33^{c}$ & NA & $1 \pm 0.43$ \\
\hline D (Gelugor) & $5.30 \pm 0.02^{c}$ & NA & $6.27 \pm 0.05$ & $2.52 \pm 1.07^{c}$ & NA & $3.17 \pm 0.47^{\mathrm{cd}}$ & $0.95 \pm 0.34^{c}$ & NA & $1.38 \pm 0.70$ \\
\hline E (Bayan Baru) & $6.55 \pm 0.06^{\mathrm{de}}$ & $7.85 \pm 0.55^{\mathrm{d}}$ & ${ }^{\mathrm{b}} 6.35 \pm 0.06$ & $3.73 \pm 0.27^{\mathrm{cd}}$ & $3.63 \pm 0.30^{d e}$ & b3.86 $\pm 0.18^{\text {cde }}$ & $0.94 \pm 0.41^{c}$ & $1.52 \pm 0.19^{d}$ & b1.41 \pm 0.75 \\
\hline F (Hypermarket S1) & ${ }^{a} \mathrm{NA}$ & $8.49 \pm 0.13^{e}$ & NA & NA & $3.93 \pm 0.09^{e}$ & NA & ${ }^{a} \mathrm{NA}$ & $1.44 \pm 0.27^{\mathrm{d}}$ & NA \\
\hline G (Hypermarket S2) & NA & $9.12 \pm 0.46^{e}$ & NA & NA & $3.96 \pm 0.06^{e}$ & NA & NA & $1.57 \pm 0.19^{d}$ & NA \\
\hline H (Chowrasta) & NA & $8.95 \pm 0.21^{\mathrm{de}}$ & NA & NA & $3.55 \pm 0.32^{\mathrm{de}}$ & NA & NA & $1.35 \pm 0.51^{d}$ & NA \\
\hline \multicolumn{10}{|l|}{ Ponds } \\
\hline $\mathrm{A} 1$ & $6.29 \pm 0.49^{d e}$ & NA & $6.56 \pm 0.53$ & $4.1 \pm 0.07^{d}$ & NA & $3.8 \pm 0.42^{\text {cde }}$ & $0.99 \pm 0.5^{c}$ & NA & $1.63 \pm 0.28$ \\
\hline A2 & $6.48 \pm 1.07^{\mathrm{de}}$ & NA & $6.93 \pm 0.40$ & $4.16 \pm 0.18^{d}$ & NA & $4.19 \pm 0.16^{e}$ & $1.2 \pm 0.63^{c}$ & NA & $1.37 \pm 0.79$ \\
\hline B1 & $6.23 \pm 0.39^{d e}$ & NA & $6.55 \pm 0.03$ & $3.32 \pm 0.48^{c d}$ & NA & $3.09 \pm 0.08^{c d}$ & $0.79 \pm 0.29^{c}$ & NA & $0.67 \pm 0.33$ \\
\hline B2 & $6.69 \pm 0.01^{\mathrm{de}}$ & NA & $6.45 \pm 0.03$ & $2.46 \pm 0.09^{c}$ & NA & $2.90 \pm 0.84^{c}$ & $0.90 \pm 0.13^{c}$ & NA & $0.96 \pm 0.09$ \\
\hline C1 & NA & $6.28 \pm 0.45^{c}$ & $5.78 \pm 0.58$ & NA & $3.38 \pm 0.58^{\mathrm{de}}$ & $3.38 \pm 0.58$ & NA & $0.6 \pm 0.02^{c}$ & $0.6 \pm 0.22$ \\
\hline $\mathrm{C} 2$ & NA & $6.62 \pm 0.25^{c}$ & $6.35 \pm 0.47$ & NA & $3.84 \pm 0.34^{\mathrm{e}}$ & $3.92 \pm 0.22$ & NA & $0.5 \pm 0.05^{c}$ & $0.58 \pm 0.18$ \\
\hline D1 & NA & $5.77 \pm 0.39^{c}$ & $5.80 \pm 0.65$ & NA & $3.09 \pm 0.03^{d}$ & $2.39 \pm 0.60$ & NA & $0.5 \pm 0.05^{c}$ & $0.5 \pm 0.05$ \\
\hline D2 & NA & $5.98 \pm 0.58^{c}$ & $5.76 \pm 0.40$ & NA & $1.35 \pm 0.44^{c}$ & $2.28 \pm 0.27$ & NA & $0.48 \pm 0.0^{c}$ & $0.48 \pm 0.0$ \\
\hline
\end{tabular}

$\mathrm{a}=$ not available; $\mathrm{b}=$ water obtained from catfish tank; $\mathrm{c}, \mathrm{d}, \mathrm{e}=\mathrm{in}$ the same column with different superscript letters are different $(P<0.05) ; \mathrm{A} 1$ and $\mathrm{A} 2=\mathrm{catfish}$ pond use chicken offal; B1 and B2=catfish pond use commercial fish feed; C1 and C2=tilapia pond use spoiled egg; D1 and D2=tilapia pond use commercial fish feed; Total aerobic and fecal coliform counts in water samples obtained from all sources were not significant different $(P>0.05)$. E Coli was counted less than 3 MPN/gr ( 0.47 log MPN/gr) for all catfish and tilapia samples and less than $3 \mathrm{MPN} / \mathrm{mL}(0.47 \log \mathrm{MPN} / \mathrm{L})$ for all water samples.

Table 1: Total aerobic, coliform and fecal coliform counts in catfish, tilapia and water obtained from ponds and wet markets in Malaysia. 


\begin{tabular}{|c|c|c|}
\hline Ponds & Temperature $\left.{ }^{\circ} \mathbf{C}\right)$ & $\mathbf{p H}$ \\
\hline A1 & $26.5 \pm 0.5$ & $6.2 \pm 0.17$ \\
\hline A2 & $26.83 \pm 0.76$ & $6.37 \pm 0.38$ \\
\hline B1 & $26.8 \pm 0.72$ & $6.4 \pm 0.36$ \\
\hline B2 & $26.93 \pm 0.12$ & $6.3 \pm 0.21$ \\
\hline C1 & $26.47 \pm 0.06$ & $6.3 \pm 0.09$ \\
\hline C2 & $26.85 \pm 0.21$ & $6.2 \pm 0.06$ \\
\hline D1 & $26.7 \pm 0.34$ & $6.42 \pm 0.27$ \\
\hline D2 & $26.67 \pm 0.40$ & $6.49 \pm 0.28$ \\
\hline
\end{tabular}

$\mathrm{A} 1$ and $\mathrm{A} 2=$ catfish pond use chicken offal; $\mathrm{B} 1$ and $\mathrm{B} 2=$ catfish pond use commercia fish feed; C1 and C2=tilapia pond use spoiled egg; D1 and D2=tilapia pond use commercial fish feed.

Table 2: Temperature and $\mathrm{pH}$ of water obtained from ponds in Malaysia.

samples exceeded the recommended microbiological standard. International Commission of Microbiological Specific for Foods [13] stated that the total aerobic bacteria in fresh and frozen fish should be less than $5.7 \log \mathrm{g}^{-1}$ to meet Good Manufacturing Practise Criteria. However, $1 / 32$ of catfish and 20/32 of tilapia samples were observed to be more than $7 \log \mathrm{cfu} \mathrm{g}^{-1}$ which exceeded the safety or quality limit standard. International Commission of Microbiological Specific for Foods [13] revealed that the total aerobic bacteria in fresh and frozen fish should be less than $7 \log \mathrm{g}^{-1}$ to meet safety or quality standard.

\section{Coliform, fecal coliform and E. coli}

The coliform count ranged from 1.46 to $4.18 \log$ MPN gr ${ }^{-1}$ for catfish, 1.6 to $4.04 \log \mathrm{MPN} \mathrm{gr}^{-1}$ for tilapia, and 2.04 to $4.36 \log$ MPN $\mathrm{mL}^{-1}$ for water. The coliform count was significant different $(\mathrm{P}<0.05)$ among catfish obtained from pond A1-A2 (chicken offals feed) and pond B2 (commercial fish feed). Similarly, there was the significant different $(\mathrm{P}<0.05)$ among tilapia obtained from pond $\mathrm{C} 1-\mathrm{C} 2$ (spoiled eggs feed) and pond D2 (commercial fish feed). Coliform count in water samples obtained from pond A2 (chicken offals feed) was also significant different $(\mathrm{P}<0.05)$ with those obtained from pond $\mathrm{B} 1-\mathrm{B} 2$ (commercial fish feed) (Table 1). However, coliform count in water samples obtained from pond C1-C2 (spoiled eggs feed) and pond D1-D2 (commercial fish feed) was not significant different $(\mathrm{P}>0.05)$. Similarly, the coliform count was not significant different $(P>0.05)$ among water samples obtained from catfish tank at each wet market.

Fecal coliform ranged from 0.48 to $1.63 \log \mathrm{MPN} \mathrm{g}^{-1}$ for catfish, 0.48. to $1.81 \log \mathrm{MPN} \mathrm{g}^{-1}$ for tilapia, 0.48 to $1.97 \log \mathrm{MPN} \mathrm{mL} \mathrm{m}^{-1}$ for water. There was not significant different $(\mathrm{P}>0.05)$ between fecal coliform in catfish obtained from wet market and pond. This was also not significant different between fecal coliform in tilapia obtained from wet market and pond. Similarly, fecal coliform was not significantly different $(\mathrm{P}>0.05)$ between water obtained from wet market and pond.

In this present study, E. coli was found for less than $3 \mathrm{MPN} \mathrm{g}^{-1}$ for catfish, tilapia and water. There was no significant different $(\mathrm{P}>0.05)$ between water obtained from wet market and pond. Similar statistics results were also observed in catfish and tilapia obtained from wet market and pond.

\section{Temperature and $\mathrm{pH}$}

This present study observed temperature of water ponds ranged from 26 to $27.5^{\circ} \mathrm{C}$ (Table 2). Temperature of water in catfish tank obtained from different wet market was no significant difference $(\mathrm{P}>0.05)$. This was also observed in temperature of water ponds. There was no significant difference $(\mathrm{P}>0.05)$ between temperature of water ponds in Pond A1, A2, B1, and B2. This present study also observed that $\mathrm{pH}$ of water ponds ranged 6 to 6.8 (Table 2). There is no significant different $(\mathrm{P}>0.05)$ between $\mathrm{pH}$ of water obtained from wet market $\mathrm{A}$, $\mathrm{B}, \mathrm{C}, \mathrm{D}$ and $\mathrm{E}$. The similar statistical analysis result was also observed in wet market $\mathrm{E}, \mathrm{F}, \mathrm{G}$ and $\mathrm{H}$. There is no significant different $(\mathrm{P}>0.05)$ between $\mathrm{pH}$ of water obtained from Pond A1, A2, B1 and B2. This was also observed in $\mathrm{pH}$ water obtained from Pond $\mathrm{C} 1, \mathrm{C} 2, \mathrm{D} 1$ and $\mathrm{D} 2$. However, $\mathrm{pH}$ of water pond obtained from Pond A1, A2, C1, and C2 was relatively higher compared to those obtained from Pond B1, B2, D1, and D2.

\section{Discussion}

The results showed variation in total aerobic count in water form ponds, and catfish and tilapia from wet markets and ponds. The highest total aerobic count was observed in tilapia obtained from wet market $\mathrm{H}$. This result similar to Shinkafi and Ukwaja [14] whom reported the high load of bacteria in tilapia sold in the central market of Sokoto Nigeria. The present study found that tilapia was not delivered as live fish but fresh or chilled fish. This condition might alter the growth of bacteria in the fish due to the spoiled process and temperature of storage. Keller [15] revealed that bacteria might increase due to the temperature and time of storage. Other study reported that spoilage was evident after $13 \mathrm{~h}$ at room temperature $\left(26-29^{\circ} \mathrm{C}\right)$ in fresh common carp (Cyprinus carpio L) [16].

This present study indicated that type of feed did not affect to the bacterial load in the fish. The nutrient of different feed was shown to be similar each other for the growth of bacteria. The present study also found that high bacterial load in fish occurred in the high temperature of water. Catfish and tilapia are cold-blood animals and have the same temperature as their surroundings [17]. Al-harbi [18] reported that temperature of water correlated with the load of bacteria in fish. In the present study, temperature of water ranged from 26 to $27.5^{\circ} \mathrm{C}$. Adam and Moss [19] revealed that mesophiles and psychrotrops bacteria grew in the ranges of 15 to $47^{\circ} \mathrm{C}$ and -5 to $35^{\circ} \mathrm{C}$, respectively. Boyd and Tanner [20] reported that coliform in catfish ponds at Auburn. Alabama was greater in summer and spring compared to other seasons when the temperature was going to decrease.

This present study observed that $\mathrm{pH}$ of water ranged from 6 to 6.8 . However, $\mathrm{pH}$ of earthen pond water (3/12) and $\mathrm{pH}$ of ex-mining pools water $(12 / 12)$ was exceeded from the recommended $\mathrm{pH}$.

Chapman [21] revealed that the recommended $\mathrm{pH}$ of water pond ranged from 6.5 to 9 for catfish farming. Ross [22] stated that the recommended $\mathrm{pH}$ of water pond for tilapia farming ranged from 7 to 9 . Accumulation of waste feed and fish faecal material results in changes in the sediment, characterized by high content of organic material and accumulation of nitrogenous and phosphorous compounds which may induce the benthic communities [23] and affect the $\mathrm{pH}$ of water ponds [24]. Fish will be stressed and die if the $\mathrm{pH}$ reach below 5 or above 10 [24]. In the present study, the depth of ponds was ranging from 4 to $7 \mathrm{~m}$ for catfish ponds and 18 to $50 \mathrm{~m}$ for tilapia ponds. Tilapia was farmed in ex-mining pools. Mente et al. [23] revealed that the growth of benthic algal bloom occurred in the depth ranging from 20 to $50 \mathrm{~m}$. Thus, this may induce the $\mathrm{pH}$ changes in water ponds and promote the stress of the fish.

This study found that coliform in catfish and tilapia fed with chicken offals or spoiled eggs were relatively higher compared to those fed with commercial fish feed. These were observed also in water samples. Boyd and Tanner [20] reported that the high organic matter input in feed could increase the coliform in the catfish ponds. Other 
Citation: Budiati T, Rusul G, Wan-Abdullah WN, Ahmad R, Arip YM (2015) Microbiological Quality of Catfish (Clarias Gariepinus) and Tilapia (Tilapia Mossambica) Obtained from Wet Markets and Ponds in Malaysia. J Aquac Res Development 6: 291. doi:10.4172/2155-9546.1000291

study reported that chicken [25] and eggs [26] were potential agents for coliform. Thus, chicken offals and spoiled eggs introduced to the aquaculture system will increase coliform and reduce the hygiene level in the ponds.

This study indicated that the level of coliform correlated to the density of the ponds. The density of fish in the ponds ranged from 10 32 of catfish $\mathrm{m}^{-2}$ and 6-10 of tilapia $\mathrm{m}^{-2}$. Coliform count was shown to be relatively higher in catfish compared to tilapia. These were also observed in water samples (Table 1). Previous study revealed that high density of fish related with coliform and other bacteria in water and fish [27].

Besides that, stream and hold water used in earthen ponds and exmining pools might be contaminated by coliform bacteria. Vŝetičková and Adámek [28] reported that the pattern of water quality changes after the flow through the pond was predominantly influenced by inlet water quality. Francy et al. [29] reported that total coliform in 136 stream and 143 ground water samples collected in five hydrology system of the United States were found in $99 \%$ and $20 \%$, respectively. That study reported that the land use related to the density of coliform in stream water. Francy et al. [29] also reported that the presence of septic systems and well depth related with the density of coliform in ground water. Blogoslawski et al. [30] reported that pathogenic bacteria can introduce to the hatchery systems though a contaminated water source.

The coliform level was found relatively higher in fresh or chilled tilapia compared to live catfish in wet markets. The coliform level might promoted the deterioration in tilapia and increase the density of coliform. Gelman et al. [16] reported that spoilage was evident after $13 \mathrm{~h}$ at room temperature $\left(26-29^{\circ} \mathrm{C}\right)$ in fresh common carp (Cyprinus carpio L).

This study found that the density of fecal coliform was observed to be significant different $(\mathrm{P}<0.05)$ in tilapia which were sold in wet market and reared in ponds. These might be occurred due to deterioration in tilapia. Keeping alive tilapia during distribution will make the high cost of transport, water and storage tanks. Thus, this fish was delivered as fresh or chilled tilapia in wet markets. Geldreich and Clarke [31] reported that the fate of fecal coliforms in the fish indicated that these organisms can probably survive and multiply when fish temperatures were $20^{\circ} \mathrm{C}$ or higher, but only when the organisms are retained in the gut for periods beyond $24 \mathrm{~h}$. Moreover, the human health risk may rise when E. coli contaminate the fish. The present study found level of total aerobic bacteria, coliform and fecal coliform in catfish, tilapia and water increase and exceed the microbiological standard due to the use of chicken offal and spoiled egg as feed.

\section{Conclusions}

Chicken offals and spoiled eggs can be potential source for the bacterial contamination to water and fish. This evidence highlights the importance of feed quality in aquaculture system.

\section{Acknowledgment}

Financial assistance provided by MOSTI (305/PTEKIND/613512) is gratefully acknowledged.

\section{References}

1. Department of Fisheries Malaysia (2010) Annual fishery statistic 2010. Department of Fisheries Malaysia, Malaysia

2. http://www.fao.org/fishery/countrysector/naso malaysia/en Cited 5 November 2014.
3. Delgado CL, Wada N, Rosegrant MW, Meijer S, Ahmed M (2003) The future of fish issues and trends to 2020. International Food Policy Research Institute Washington DC, USA.

4. Focardi S, Corsi I, Franchi E (2005) Safety issues and sustainable development of European aquaculture: new tools for environmentally sound aquaculture. Aquacul Inter 13: 3-17

5. Workagegn KB, Ababbo ED, Tossa BT (2013) The Effect of Dietary Inclusion of Jatropha curcas Kernel Meal on Growth Performance, Feed Utilization Efficiency and Survival Rate of Juvenile Nile tilapia. J Aquacul Res Develop. 4: 193.

6. Workagegn KB, Ababboa ED, Yimer GT, Amare TA (2014) Growth Performance of the Nile Tilapia (Oreochromis niloticus L.) Fed Different Types of Diets Formulated From Varieties of Feed Ingredients. J Aquacul Res Develop 5: 235.

7. Lunestad BT, Nesse L, Lassen J, Svihus B, Nesbakken T, et al. (2007) Salmonella in fish feed; occurrence and implications for fish and human health in Norway. Aquaculture 265: 1-8.

8. http://www.fao.org/docrep/003/V4430E/N4430E00.HTM. Cited 10 Agustus 2012

9. http://www.fda.gov/Food/ScienceResearch/LaboratoryMethods/

10. http://www.fda.gov/Food/ScienceResearch/LaboratoryMethods/ BacteriologicalAnalyticalManualBAM/ucm064948.htm. Cited 1 September 2008

11. World Health Organization (1989) Health Guidelines for the Use of Wastewate in Agriculture and Aquaculture. World Health Organization, Geneva, Switzerland

12. Department of Agriculture, Animal Health and Product (2004) Animal and animal origin foods.

13. International Commision of Microbiological Spesific for Foods (1986) Microorganisms in Foods 2. Sampling for Microbiological Analysis: Principles and Specific Applications. Blackwell Scientific Publication, Oxford, United Kingdom.

14. Shinkafi SA Ukwaja VC (2010) Bacteria Associated with Fresh Tilapia Fish (Oreochromis niloticus) Sold At Sokoto Central Market in Sokoto, Nigeria. Nig J Bas App Sci 18: 217-221.

15. Keller JJ (2004) Employee Food Safety Handbook. Kelly and Associates Inc Neenah, Wisconsin.

16. Gelman A, Pasteur R, Rave M (1990) Quality changes and storage life of common carp (Cyprinus carpio) at various storage temperatures. J Sci Food Agricul 52: 231-241.

17. Swann L, Morris JE, Selock, DE, Riepe J (1994) Cage Culture of Fish in the North Central Region Site selection. lowa State University, Ames, lowa.

18. Al-harbi $\mathrm{AH}$ (2003) Faecal coliforms in pond water, sediments and hybrid tilapia Oreochromis niloticus x Oreochromis aureus in Saudi Arabia. Aquacul Res 34 517-524.

19. Adam MR, Moss MO (2004) Food microbiology. The Royal of Chemistry. Cambridge, United Kingdom.

20. Boyd CE, Tanner M (1998) Coliform organism in water of channel catfish ponds. J Wor Aquacul Soc 29: 74-78.

21. http://edis.ifas.ufl.edu/fa010.

22. Ross LG (2000) Environmental physiology and energetics. Kluwer Academic Publishers. Dordrecht, Netherlands.

23. Mente E, Pierce GJ, Santos MB, Neofitou C (2006) Effect of feed and feeding in the culture of salmonids on the marine aquatic environment: a synthesis for European aquaculture. Aquacul Intern 14: 499-522.

24. https://srac.tamu.edu/index.cfm/event/getFactSheet/whichfactsheet/112. Cited 29 Agustus 2012

25. Rodrigo S, Adesiyun A, Asgarali Z, Swanston W (2006) Occurrence of selected foodborne pathogens on poultry and poultry giblets from small retail processing operations in Trinidad. J Food Prot 69: 1096-1105.

26. Jones DR, Anderson KE, Guard JY (2012) Prevalence of coliforms, Salmonella, Listeria, and Campylobacter associated with egg and the environment of conventional cage and free-range egg production. Poult Sci 91: 1195-1202.

27. Mandal, SC, Hasan M, Rahman MS, Manik MH, Mahmud ZH, et al. (2009) 
Citation: Budiati T, Rusul G, Wan-Abdullah WN, Ahmad R, Arip YM (2015) Microbiological Quality of Catfish (Clarias Gariepinus) and Tilapia (Tilapia Mossambica) Obtained from Wet Markets and Ponds in Malaysia. J Aquac Res Development 6: 291. doi:10.4172/2155-9546.1000291

Page 5 of 5

Coliform Bacteria in Nile Tilapia (Oreochromis niloticus) of Shrimp-Gher, Pond and Fish Market. Wor J Fish Mar Sci 1: 160-166.

28. Vŝetičková L, Adámek Z (2012) The impact of carp pond management upon macrozoobenthos assemblages in recipient pond canals. Aquacul Intern 21 : 897-925.

29. Francy DS, Helsel DR, Nally RA (2000) Occurrence and distribution of microbiological indicators in groundwater and stream water. Water Environ Res 72: 152-161.

30. Blogoslawski WJ, Stewart ME, Rhodes EW (1978) Bacterial disinfection in shellfish hatchery disease control. Proc ann mee-Wor Maricul Soc 9: 587-602.

31. Geldreich, EE, Clarke NA (1966) Bacterial pollution indicators in the intestinal tract of freshwater fish. Appl Microbiol 14: 429-437. 